\title{
Sivil Toplum Kuruluşları Bağlamında İmam Hatip Liseleri: Güncel Tartışmalar ve Öneriler
}

\section{Sümeyra ARICAN}

\begin{abstract}
Öz: İmam hatip liseleri en yoğun tartışmaların yaşandığı eğitim kurumlarından biri olarak dikkat çekmektedir. Hem imam hatip liseleri odağında kurumlaşan sivil kuruluşlar hem de eğitimle ilgilenen sivil kuruluşlar imam hatip lisesi meselesini gündeme almaktadırlar. Bilhassa son 8 yıldır niceliksel olarak artışa geçen ve eğitim sistemindeki etkinliğini daha da yoğun olarak hissettiren imam hatip liseleri hakkındaki tartışmalar yoğunlaşmış durumdadır. Meseleyi sivil toplum kuruluşlarının yayınladığı araştırma raporları çerçevesinde ele alan bu araştırma, güncel tartışmaların içeriğine odaklanmakta ve sivil toplum kuruluşlarının görüşlerini ve sunulan çözüm önerilerini, karşılaştırmalı olarak ortaya koymayı amaçlamaktadır. Nitel çoklu durum çalışması olarak tasarlanan bu araştırmada, maksimum çeşitlilik örneklemesi ile seçilen sivil toplum kuruluşlarının çalışmalarından edinilen veriler iki ana tema halinde ele alınmıştır. Bu temalar; "Niteliksel ve Niceliksel Bağlamlar "ve "STK Önerileri" olarak belirlenmiştir. Araştırmada, STK'ların bu okulların dini ve akademik eğitimlerine yönelik eleştirileri ve sorunların çözümüne yönelik önerileri ortaya konmuştur.
\end{abstract}

Anahtar Kelimeler: Din Eğitimi, Mesleki Din Eğitimi, İmam Hatip Lisesi, Sivil Toplum Kuruluşu, Eğitimde Nicelik ve Nitelik.

\section{Imam-Hatip High Schools in the Context of Non-Governmental Organizations: Current Discussions and Suggestions}

\begin{abstract}
Imam-Hatip high schools stand out as one of the most debated educational institutions. Not only the non-governmental organizations that are institutionalized with Imam-Hatip high schools as their focus but also the non-governmental organizations dealing with education put the issue of Imam-Hatip high schools on their agendas. Particularly, discussions have intensified about Imam-Hatip high schools, which have increased quantitatively in the last 8 years and made their effectiveness in the education system more intense. This research, which handles the issue within the framework of research reports published by non-governmental organizations, focuses on the content of current discussions and aims to comparatively reveal the views of non-governmental organizations as well as the proposed solutions. In this study, which is designed as a qualitative multiple case study, the data obtained from the studies of non-governmental organizations that were selected with maximum diversity sampling were discussed under two main themes. These themes are determined as "Qualitative and Quantitative Contexts" and "NGO Recommendations". In the study, criticisms of NGOs towards the religious and academic education in these schools and suggestions for solving the problems were presented.
\end{abstract}

Keywords: Religious Education, Vocational Religious Education, Imam-Hatip High Schools, Non-Governmental Organizations, Quantity and Quality in Education. 


\section{Giriş}

Türkiye'de sivil toplum yapısının kurumsallaşmasının Avrupa Birliği kapsamındaki açılımlar sonrasında 2004 yılı itibariyle hız kazandığı görülmektedir.' Son 30 yıldır sivil toplum kuruluşlarının diğer alanlar yanı sıra eğitim alanında da etkinliğini artırdığı, çalışmalarını hızlandırdığı gözlenmektedir. Sivil toplum kuruluşları hazırladıkları/hazırlattıkları araştırma raporlarıyla, yayınladıkları bültenler ve yaptıkları basın açıklamalarıyla eğitim alanındaki görüşlerini kamuoyuyla paylaşmaktadırlar. Onların tüm bu faaliyetleri aynı zamanda politik uygulamaları etkilemeye, değiştirmeye yönelik çabalar olarak görülmektedir.

Sivil toplum kuruluşları eğitime ve eğitim sistemine yönelik pek çok meseleyle ilgilenmektedir. Bunlar arasında örgün eğitimin özgün kurumlarından biri olarak mesleki din öğretimi faaliyetlerini gerçekleştiren imam hatip liseleri de bulunmaktadır. Mesleki din öğretimi kurumu olan imam hatip liselerinin tarihsel süreci 1924 yılında kabul edilen Tevhid-i Tedrisat Kanunu ile başlamıştır. Bu okullar için tarihi süreçte pek çok uygulama denenmiş, sürekli değişiklikler yaşanmıştır. Zaman zaman ortaokul kısımları kapatılmış ya da tekrar açılmış, üniversiteye giriş durumlarında kısıtlamalar ya da genişlemeler uygulanmıştır². Yakın tarihlerde, 1997 yılında bu okulların orta kısımları kapatılmış, mezunlarına üniversite sınavında katsayı uygulaması getirilmiştir. 2011 yılında katsayı uygulamasının kaldırılması akabinde öğrenci sayıları artmaya başlayan bu okullar, 2016 yılından itibaren proje liseleri ${ }^{3}$ olarak da kurumsallaşmaya başlamış, yeni açılan okulların bir kısmı proje okulu olarak yapılandırılmıştır. ${ }^{4}$ Proje okulları kapsamında uluslararası Anadolu imam hatip liseleri ${ }^{5}$ de açılmıştır.

1 Ömer Çaha, Sivil Toplum Sivil Topluma Karşı, (İstanbul: Mana Yayınları, 2017), 93.

2 Bkz. Halis Ayhan, Türkiye'de Din Eğitimi, (İstanbul: Marmara Üniversitesi İlahiyat Fakültesi Vakfı Yayınları, 1999), 31-38; Ahmet Ünsür, Kuruluşundan Günümüze Imam-Hatip Liseleri, (İstanbul: Ensar Neşriyat, 2005), 148-178; 165-208. İmam hatip liselerinin ilk dönemleri hakkında ayrıca bk. İsmet Parmaksızoğlu, Türkiye'de Din Eğitimi, (Ankara: Milli Eğitim Basımevi, 1966); Nihat Dinçer, 1913'ten Günümüze Imam-Hatip Okulları Meselesi, (İstanbul: Yağmur Yayınevi, 1974. Kurumları Yönetmeliği.

4 İmam hatip liselerine kendi programlarının yanı sıra fen, sosyal bilimler, yabancı dil, sanat, spor liseleri programlarını da uygulama hakkı verilmesi Eğitim-ı̇ş Sendikası tarafından mahkemeye taşınmıştır. 70'den fazla ülkeden gelen öğrencilerin öğrenim gördüğü bu kurumların ilki 2006-2007 yılında Kayseri'de açılmıştır. Sonraki yıllarda 3 tanesi İstanbul'da olmak üzere Konya, Bursa, Sivas ve Eskişehir'de de öğrenime başlamışlardır. Şu an mevcut Uluslararası AiHL sayısı 13'tür. "Uluslararası Anadolu İmam Hatip Liseleri," erişim 13 Ekim 2020, http://dogm.meb.gov.tr/pdf/UAIHL_Tanitim.pdf. 
2020 yılı itibarıyla Anadolu imam hatip liseleri bünyesinde uygulanan programlar/projeler

- Fen ve sosyal bilimler programı/projesi uygulayan Anadolu imam hatip liseleri

- Geleneksel, görsel ve çağdaş sanatlar, musiki ve spor programı/ projesi uygulayan Anadolu imam hatip liseleri

- Uluslararası Anadolu imam hatip liseleri

- Hafız öğrencilerin eğitim gördüğü Anadolu imam hatip liseleri

- Hazırlık sınıfı ile dil projesi uygulayan Anadolu imam hatip liseleri (MEB, 2020) şeklindedir.

Şüphesiz imam hatip liselerindeki güncel değişimler pek çok yönden dikkatleri çekmektedir. İmam hatip liselerine dair güncel meselelere sivil toplum kuruluşlarının da uzak kalmadıkları gözlenmektedir. Bu bağlamda sivil toplum kuruluşlarının imam hatip liselerine yönelik görüşlerinin bilimsel bir yaklaşımla ele alınmasına ve değerlendirilmesine intiyaç duyulmaktadır.

\section{Araştırma Problemi}

Sivil toplum kuruluşlarının peş peşe yayınladıkları araştırma raporları, bültenler, demeçler, gerçekleştirdikleri çalıştaylar ve bilimsel toplantılar ile genelde eğitim, özelde din eğitimiyle ilgili meselelerle ilgilendikleri gözlenmektedir. Bununla birlikte imam hatip liseleri özelinde gerçekleştirilen çalışmalar da dikkat çekmektedir. Tüm bu çalışmalarla, giderek artan şekilde, hem politik baskı unsuru olarak konumlanma hem de eğitim sistemine yönelik önerilerle etkide bulunma gayesi dikkat çekmektedir. İmam hatip liselerinin odağa alındığı tartışmalar ve sunulan çözüm önerilerinin sistematik olarak ele alınma gerekliliği hissedilmiştir. Bu sebeple araştırmanın ana konusu, imam hatip liseleri hakkında son dönem gelişmeler ışığında yaşanan güncel tartışmaları ve sunulan çözüm önerilerini sivil toplum kuruluşları yayınları üzerinden incelemek olarak belirlenmiştir. $\mathrm{Bu}$ çalışmada, 2012-2020 yılları arasında imam hatip liseleri bağlamında Türkiye'de sivil toplum kuruluşlarının gündemine konu olan tartışmaların içeriği ve çözüm önerileri ele alınmaktadır. Söz konusu tarihlerin belirlenmesinde, eğitim sisteminin değişmesi ve kesintili eğitime geçişin başlangııında içinde bulunulan yıla kadar olan sürenin değerlendirilmek istenmesi etkili olmuştur.

Bu çerçevede araştırmanın temel problemi sivil toplum kuruluşlarının imam hatip liselerine yönelik güncel görüşleri ve önerileri nelerdir? sorusudur. 


\section{Araştırmanın Amacı ve Önemi}

Bu araştırma, sivil toplum kuruluşlarının imam hatip liselerinin güncel durumlarına ilişkin değerlendirmelerini ve ileri sürdükleri çözüm önerilerini kendi araştırmalarından hareketle ele almayı amaçlamaktadır. Literatür taraması sonucunda imam hatip liselerine dair güncel gündemi sivil toplum kuruluşları açısından ele alan bir çalışmaya rastlanmamıştır. İmam hatip liselerine dair güncel gündemin ele alındığı bu çalışma ile din eğitimi alanına katkıda bulunmak hedeflenmiştir. İmam hatip liselerine dair tartışmalı konuların ve sunulan önerilerin karşılaştırılmalı olarak ele alınması ile meseleye dair daha geniş bir çerçeve sunulması amaçlanmıştır. Çalışma ile imam hatip liselerine dair pedagojik uygulamaların geliştirilmesi noktasında katkı sağlanması da umulmaktadır.

\section{Yöntem}

Bu bölümde; araştırma deseni, çalışma grubu, verilerin toplanması ve analizi aşamasında kullanılan tekniklerle ilgili bilgiler yer almaktadır.

\subsection{Araştırma Deseni}

Bu çalışma için, nitel bütüncül çoklu durum deseni uygun görülmüştür. Araştırma için söz konusu desenin seçiminde, ele alınan durumların bütüncül olarak değerlendirilmesinin ardından diğer durumlarla karşılaştırılmak istenmesi etkili olmuştur. ${ }^{6}$

\section{2. Çalışma Grubu}

Araştırmanın çalışma grubunun belirlenmesinde amaçlı örnekleme yöntemlerinden maksimum çeşitlilik örneklemesi yöntemi kullanılmıştır. Bu örnekleme biçiminde belirlenen durumlar (bireyler, gruplar, kurumlar ya da diğer olaylar) çeşitliliği yansıtacak şekilde amaçlı olarak seçilmekte, böylece durumların ortak yanlarını belirlemek, her bir durumu ayrıntılı olarak ele almak ve problemin farkı boyutlarını ortaya koymak amaçlanmaktadır.? ları, 2018), 301-303. 
Sivil toplum kuruluşlarının eğitim veya din eğitimi hakkında rapor yayınlamış olmaları örneklemeye alınmaları için belirleyici etken olmuştur. Rapor yayınlamamış olan kurumlar kapsam dışında bırakılmış, yayınlanmış raporların da araştırma konusuyla ilgili olanları değerlendirilmiştir.

Araştırma kapsamında incelenen kuruluşlar; Eğitimsen, Eğitim-Bir-Sen, Türk Eğitim-Sen, Eğitim Reformu Girişimi (ERG), İLKE İlim ve Kültür Derneği, Türkiye İmam Hatipliler Vakfı (TiMAV), Türk Eğitim Derneği (TED), Ensar Vakfı/Değerler Eğitimi Merkezi (DEM) ve Yurttaşlık Derneği olmuştur. Seçilen kuruluşların veri zenginliği ve çeşitliliğini sağlayacak nitelikte olmalarına dikkat edilmiştir.

\subsection{Verilerin Toplanması}

Araştırmanın verilerinin toplanması sürecinde doküman incelemesi yolu tercih edilmiştir. Sivil toplum kuruluşları tarafından hazırlanan ya da hazırlatılan araştırma raporları ve diğer yayınlar incelenmiştir. Bu çalışmalar kurumların görüşlerini içermesi dolayısıyla zengin veri kaynağı olarak değerlendirilmektedir. ${ }^{8}$ Dokümanlar karşılaştırmalı olarak değerlendirilmiş, benzerlik ve farklılıkları tespit edilmiştir.

\subsection{Verilerin Çözümlenmesi}

Çalışmada betimsel analiz yöntemi tercih edilmiştir. ${ }^{9}$ Verilerin kodlanması sürecinde temalar tümevarım yöntemi kullanılarak belirlenmiştir. Elde edilen veriler incelenerek kodlanmış, kodlar bir araya getirilerek ortak ve de farklı yönleri açısından bir araya getirilerek sınıflandırılmıştır. Çalışma sürecinde veriler en az üç kez gözden geçirilmiş, tekrar tekrar okunarak değerlendirilmiştir. Veriler araştırmacı tarafından toplanmış ve yorumlanmıştır. Sivil toplum kuruluşlarına ait dokümanlardan edinilen veriler, tartışma bölümünde alanyazında yer alan çalışmalarla karşılaştırmalı olarak ele alınmıştır.

\section{Bulgular}

Çalışma bulguları iki ana tema olarak detaylandırılmıştır. Bu temalar; niteliksel ve niceliksel bağlamlar ve STK önerileri olarak belirlenmiştir. Ayrıca söz konusu temalara ait kategorilere de yer verilmiştir. 


\subsection{Niteliksel ve Niceliksel Bağlamlar}

İmam hatip liselerine dair tartışmaların odak noktasında bu kurumların kalitesi ve sayısal çokluğu yer almaktadır. Özellikle son yıllarda yaşanan sayısal yükseliş̧ dikkatlerin tekrar bu kurumlara çevrilmesine neden olmuş, bununla birlikte nitelikleri de daha bir dikkatle sorgulanır olmuştur. İmam hatip liselerinin artan öğrenci sayıları sadece son yıllarda değil, önceki yıllarda da ara ara gündeme alınmıştır. ${ }^{10}$ Tartışılan bir diğer önemli mesele ise bu kurumların eğitim niteliğidir.

\subsection{1. Öğrenci Sayıları}

İmam hatip liselerindeki niceliksel artış yakın tarihlerde yaşanan gelişmelerin bir sonucu olarak görülmektedir. 1997 yılında 8 yıllık zorunlu ve kesintisiz eğitim modeline geçilmesiyle birlikte imam hatip liseleri bünyesinde yer alan ortaokul kısmı kapatılmış, üniversiteye geçişte ise katsayı uygulaması getirilmişti. Bu durum öğrenci sayılarında azalma ile sonuçlanmıştı. Bazı sivil toplum kuruluşları çalışmalarında bu hususlara değinildiği görülmektedir.

Eğitimciler Birliği Sendikası'na göre yapılan bu değişikliklerle sadece imam hatip liseleri değil temel eğitim de olumsuz etkilenmiştir." Daha önce uygulanan kesintisiz eğitim modeli pedagojik bulunmamakta, askeri darbe sonrası siyasilere yaptırımlarla uygulandığı düşünülmektedir. ${ }^{12} 2012$ yılında 4+4+4 olarak isimlendirilen kesintili eğitim modeline geçilmesi din eğitiminin ve mesleki eğitimin önünün açılması olarak algılanmış ve olumlu karşılanmıştır. ${ }^{13}$ Nitekim gerçekleştirilen değişiklikler neticesinde imam hatip liselerinin ortaokul kısımları bağımsız olarak ya da liseler bünyesinde yeniden açılmış, öğrenci sayılarında belirgin artışlar yaşanmıştır. Nitekim Eğitim Reformu Girişimi (ERG)'nin, Türk Eğitim Derneği (TED)'nin, İLKE Derneği'nin yıllık olarak yayınlanan eğitim izleme raporlarında ${ }^{14}$ bu artışların sa-

Bu konuda TÜSIAAD’ın 1990 yılında hazırlattığı çalışmaya bakılabilir. Ayrıca benzer eleştiriler Eğitimsen'in 2000 yılı olağan kongresinde de dile getirilmiştir.

11 Eğitimciler Birliği Sendikası (Eğitim-Bir-Sen), Rakamlarla 28 Şubat Raporu, (Ankara: Eğitimciler Birliği Sendikası, 2014).

12 Mehmet Bahçekapılı. Türkiye'de Din Eğitiminin Dönüşümü (1997-2012), (ILKE İlim Kültür Eğitim Derneği, 2014).

13 TiMAV, Türkiye'de Din Öğretimi Forumu Sonuç Raporu, Konya: 2012.

14 Bkz. TEDMEM. (2020). 2019 Eğitim Değerlendirme Raporu, (Ankara: Türk Eğitim Derneği, 2020); TEDMEM. 2018 Eğitim Değerlendirme Raporu, (Ankara: Türk Eğitim Derneği, 2019); Yusuf Alpaydın. Geleceğin Türkiyesinde Eğitim, (İstanbul: ILLE İlim Kültür Eğitim Vakfı, 2018); ILKE İlim Kültür Eğitim 
yısal verilerle ortaya konulduğu görülebilir. Son güncel verilere göre imam hatip lisesi öğrenci sayısı" 2015-2016 yılında en yüksek değeri olan 555.870'e ulaşırken, 2016-2017 ve 2018- 2019 yıllarında azalarak 498.002 olmuştur."15 Imam hatip liselerinin öğrenci sayıları konusunda sivil toplum kuruluşlarınca farklı değerlendirmeler yapılmaktadır. Bir yandan bu sayıların devlet eliyle de desteklenerek artırılması, diğer yandan öğrenci sayılarındaki düşüşe rağmen okul sayılarının artırılmaya çalışılması eleştirilirken, diğer taraftan öğrenci sayılarının yetersiz olduğu ve yükseltilmesi gerektiği konusunda öneriler sunulmaktadır.

ILKE Vakfı çalışmasında ${ }^{16}$ imam hatip okullarının kapasitelerinin ve öğrenci oranlarının artıııması gerektiğini vurgulanmaktadır. MEB tarafından teşvik edilmesine rağmen Türkiye'nin özgün bir modeli olan imam hatip liselerine olan talebin düşük olduğuna ve artırılması için yeni politikalar geliştirilmesi gerektiğine dikkat çekilmektedir. ${ }^{17}$ Öte yandan Eğitimsen, Milli Eğitim Bakanlığının, imam hatip ortaokullarını ödenek ve devlete devredilen özel okulların tahsisi gibi diğer imkânlarla açıkça teşvik etmesini ve böylelikle okul ve öğrenci sayısındaki artışın ${ }^{18}$ devlet eliyle desteklenmesini eleştirmektedir. Öğrenci sayılarının artırılması gerektiğine dair bir ibaresi bulunmamakla birlikte Türk Eğitim Derneği (TED) de ${ }^{19}$ öğrenci sayılarındaki düşüşe dikkat çekmekte, bu düşüşün, okul sayılarının artmasına rağmen gerçekleştiğini vurgulamaktadır.

\subsubsection{Yapılanma}

İmam hatip liseleri ile diğer lise türleri arasında; fiziki imkanlar, okul inşaatları, derslikler, sosyal ve kültürel faaliyet bütçeleri gibi konulardaki farklılıklara dikkat çekilmektedir.

İmam hatip liselerindeki öğrenci sayılarının son yıllarda azaldığını vurgulayan Türk Eğitim Derneği² 2019 yılı için öngörülen yeni okul yatıımlarını, öğrenci

Vakfı. Eğitim İzleme Raporu -2019-, (İstanbul: ILKE Illim Kültür Eğitim Vakfı, 2020); Eğitim Reformu Girişimi. Eğitimin Iç̧eriği Eğitim İleme Raporu 2020, (İstanbul: Eğitim Reformu Girişimi, 2020); Eğitim Reformu Girişimi. Eğitim İleme Raporu 2017-2018, (İstanbul: Eğitim Reformu Girişimi, 2018).

TEDMEM. 2019 Eğitim Değerlendirme Raporu, 208.

Alpaydın, Geleceğin Türkiyesinde Eğitim, 117.

Alpaydın, Geleceğin Türkiyesinde Eğitim, 59.

IHO öğrenci sayısı 7 kat, okul sayısı 2 kat artmıştır.

TEDMEM. 2019 Eğitim Değerlendirme Raporu, 210.

TEDMEM. 2019 Eğitim Değerlendirme Raporu, 211. 
sayı artışlarıyla tutarlı olmadığı gerekçesiyle eleştirmektedir. Bu durumun, "ortaöğretim kademesindeki okullar için fiziki mekânların kullanımında rasyonel bir dağılımın ve yerleştirmenin sağlanmasındaki sınırlılıklara işaret ettiği"21 belirtilmekte, ayrıca "okul türlerine göre fizikî kaynak kullanımı ve kaynak ihtiyaçlarının yerleşim birimleri esas alınarak analiz edilmesi ve bir okul türünde atıl olan fizikî kaynakların kullanımının diğer okul türlerine olan talep doğrultusunda planlanması gerektiği"22 vurgulanmaktadır.

Ayrıca diğer ortaöğretim kurumlarıyla kıyaslandığında derslik ve öğretmen başına düşen öğrenci sayılarındaki farklılıklara da dikkat çekilmektedir. Buna göre Anadolu liselerinde derslik başına 28, fen liselerinde 22 öğrenci sayısına karşılık imam hatip liselerinde derslik başına 14 öğrenci bulunmaktadır. ${ }^{23}$ Okul türleri arasındaki bu eşitsizliklerin giderilmesi yönünde değerlendirmeler yapılmaktadır. İmam hatip liselerinin -öğrenci sayısında bir önceki yıla göre düşüş görülür iken- okul inşaatları yanı sıra kültürel ve sanatsal faaliyetleri için ayrılan yüksek bütçelere de dikkat çekilmektedir. ${ }^{24}$ Bütçe dağılımında imam hatip liseleri ile fen liseleri arasında görülen bariz farklılık ${ }^{25}$ eleştirilmektedir.

Son zamanların tartışmalı bir başka konusu olan mahallelerde bulunan devlet okullarının imam hatip ortaokuluna (iHO) ${ }^{26}$ dönüştürülmesi meselesi de gündemde yer almaktadır. Tepki çeken bu uygulamalar neticesinde bir araya gelen veliler çeşitli dernek ve platformlar ${ }^{27}$ da oluşturmaktadırlar. ${ }^{28}$ Özellikle çocuklarını bu kurumlara göndermeyi tercih etmeyen Alevi ailelerin yoğun olarak yaşadıkları mahallelerde o bölgede yaşayanların görüşleri dikkate alınmadan yaşanan

TEDMEM. 2019 Eğitim Değerlendirme Raporu, 9.

TEDMEM. 2019 Eğitim Değerlendirme Raporu, 10.

TEDMEM. 2019 Eğitim Değerlendirme Raporu, 210.

TEDMEM. 2017 Eğitim Değerlendirme Raporu, (İstanbul: Türk Eğitim Derneği, 2018).

"2017'de Eğitimde Neler Oldu," erişim 02.04.2020, http://egitimsen.org.tr/2017de-egitimde-neler-oldu/.

Güngören, Zeytinburnu, Kartal, Fikirtepe, Şişli, Beykoz, Çekmeköy'deki okullar gibi. Yasemin Zeytinoğlu, Öğretmenler, Öğrenciler, Veliler ve STK'lar Açısından Eğitim Sisteminde Din Öğretiminin Rolü, (İstanbul: Yurttaşlık Derneği, 2016), 61-62.

27 Bu bağlamda İstanbul Kadıköy'deki Yeşilbahar Ortaokulunun İHO dönüştürülmesini önlemek için oluşturulan Okuluma Dokunma Koordinasyonu, mücadele kapsamını eğitimin tek tipleştirilmesine dair itirazla genişleterek Eğitimsen; Veli-Der, Sosyal Haklar Derneği, Mayısta Yaşam Kooperatifi gibi örgütler ve Alevi dernekleriyle işbirliği içerisinde sürdürmektedir.

Zeytinoğlu, Eğitim Sisteminde Din Öğretiminin Rolü, 2016. 
dönüşümlerin dikkat çektiği belirtilmektedir. ${ }^{29}$ Üstelik fiziki altyapı sorunları en az olan, teknik olarak en donanımlı okulların imam hatibe dönüştürüldükleri, imam hatip okullarının ödenek ve kaynak sıkıntısı çekmedikleri ${ }^{30}$ ileri sürülmektedir.

Yerleşim yerlerinde Anadolu imam hatip lisesi açılabilmesi için mevcut olan 50 bin kişinin yaşaması şartının 5 bin kişiye düşürülmesi, bu okulların açılmasının kolaylaştırıldığı şeklinde yorumlanmıştır. Tartışmalar, küçük yerleşim bölgelerinde yaşayan öğrencilerin bu okullara gitmek zorunda kalacaklarına yoğunlaşmıştır. Anadolu lisesi açılabilmesi için uygulanan iki şube oluşturacak sayıda öğrenci kaydı şartının Anadolu imam hatip liseleri için söz konusu olmaması da bu okulların açılışının kolaylaştırıldığını düşündürmüştür. ${ }^{31}$

\subsubsection{Nitelik}

Öğrenci sayıları yanı sıra okullarda okuyan öğrencilerin niteliği de gündeme taşınmaktadır. Öğrencilerin niteliğine dair göstergeler, liseye ve üniversiteye giriş sınavlarındaki sonuçlar üzerinden değerlendirilmektedir.

TED'in 2015 yılında sunduğu istatistiki veriler, "öğrenci sayısında iki katı aşan nicelik artışına rağmen imam hatip liselerinin nitelik yönünden geliştirilmesi ihtiyacının devam ettiğini"32 ortaya koymaktadır. Bu kanaatin oluşmasında akademik başarısı düşük öğrencilerin bu okullara direkt kaydedilmelerinin de ${ }^{33}$ etkili olduğu düşünülmektedir.

"LYS 2017 sonuç istatistiklerine göre, İmam hatip lisesi öğrencilerinin yükseköğretim programlarına yerleşme oranı \%18'dir. [...] PISA değerlendirmesinde de meslek liselerinden sonra en düşük performans gösteren okul türü olarak belirlenen Anadolu imam hatip liselerinde eğitimin genel niteliğinin öğrenci başarısını sağlama konusunda yeterli olduğundan söz etmek güç görünmektedir." ${ }^{34}$

Nurcan Kaya, Türkiye Eğitim Sisteminde Renk, Etnik Köken, Dil, Din ve Inanç Temelli Ayrımcılık, (İstanbul: Tarih Vakfı, Uluslararası Azınlık Hakları Grubu MRG, 2015).

30 Kaya, Türkiye Eğitim Sisteminde Ayrımcılık, 2015, 54; Eğitimsen, 2017.

31 TEDMEM. 2017 Eğitim Değerlendirme Raporu, 200.

32 TEDMEM, 2015 Eğitim Değerlendirme Raporu, (Ankara: Türk Eğitim Derneği, 2015), 157. 2004 yılında TESEV tarafından yayınlanan araştırma raporuna göre de bu okullar mezunlarını üniversiteye yerleştirme açısından -Kartal AiHL gibi başarılarıyla öne çıkan okullar hariç- toplumdaki yaygın kanaatin aksine başarılı değildirler (Ruşen Çakır, İrfan Bozan ve Balkan Talu, Imam Hatip Liseleri: Efsaneler ve Gerçekler, (TESEV, 2004).

33 Türk Eğitim-Sen. Türkiye'de Din Eğitimi Çalıştayı, (Ankara: Türk Eğitim-Sen, 2015).

34 TEDMEM. 2017 Eğitim Değerlendirme Raporu, (Türk Eğitim Derneği TED, 2018), 204. 
Bu değerlendirmeler sonraki yıllar için de devam etmektedir. 2019 yılında AÖF dâhil edilmediğinde ÖSYS'ye başvuran yaklaşık dört imam hatip lisesi öğrencisinden yalnızca birinin üniversiteye yerleşebildiği ve lisansa yerleşme oranının \%14,90 olduğu ${ }^{35}$, Din Öğretimi Genel Müdürlüğü tarafından yükseköğretime geçişte imam hatip lisesi öğrencilerinin performansı gündeme alınarak Üniversiteye Doğru 2020 Projesi başlatıldığı belirtilerek, imam hatip liselerindeki eğitimin niteliğine dikkat çekilmektedir. Okulların sayı olarak artırılması yanı sıra eğitimin niteliği üzerinde durulması gerektiği de vurgulanmaktadır.

“Imam hatip liseleri sayısındaki artışın ise düzenli olarak sürdüğü görülmektedir. Bu noktada, okulların sayıca artırılmasına yönelik politikaların eğitimde sistem yaklaşımı ile okulların amaç ve işlevleri yeniden ele alınarak değerlendirilmesi, sayısal bir artış hedeflemekten çok okulların niteliği üzerinde durulması önemli görülmektedir." ${ }^{\prime 36}$

Üniversite sınavlarına yansıyan bu sonuçların muhtemel nedenlerinden biri olarak öğrencilerin liseye giriş sınavlarındaki performansları da değerlendirilmektedir. Buna göre Anadolu imam hatip liselerine yerleşen en düşük ve en yüksek yüzdelik dilime sahip öğrencilerin yüzdelik dilimleri arasındaki fark 94,08'e çıkmaktadır ${ }^{37}$. Bu durum proje okullarının amaçları açısından tartışılır görülmektedir.

Demografik gerekse fiziksel ihtiyaç ve durum analizi yapılmadan çok sayıda IHO' nun açılması veya dönüştürülmesi de isteksiz öğrencilerin bu okulları tercih etmesiyle sonuçlanmakta bu da öğrenci niteliğiyle ilgili sıkıntılar oluşturmaktadır. ${ }^{38}$ Öğrencilerin başarı puanları arasındaki farkla birlikte, 2013-2014 yıllarında TEOG sınavındaki sistemsel sıkıntılarla, bu okulları tercih etmeyen öğrencilerin otomatik olarak kaydedilmeleri de bir problem olarak dile getirilmiştir. Sivil toplum kuruluşu çalışmalarında aralarında gayrimüslimlerin de yer aldığı öğrencilerin imam hatip liselerine yerleştirildiğine, öğrencilerin evlerine uzak okullara gitmek zorunda kaldıklarına ya da başka okula gidemeyeceği için bu okullara yerleştirilen öğrencilerin gelecek endişesi taşıdığına dair ifadeler ${ }^{39}$ yer almıştır. 
İmam hatip liseleri bağlamında ayrıca okul sayısında yaşanan ani büyüme sonucunda nitelikli ve deneyimli idareci bulunamaması, özellikle yeterli sayıda meslek dersleri öğretmeni görevlendirilememesi, ücretli öğretmenlerle ihtiyacın karşılanmaya çalışılması, ihtiyaçları ve hukuki yapıları açısından farklı niteliğe sahip olan ortaokul ve liselerin çoğu zaman tek müdürle yönetilmeye çalışılması, karşılaşılan problemlerin yoğunluğunun öğretmen ve öğrencilerde kuruma olan aidiyeti zayıflatması, sosyal sorumluluk ve yardımlaşma faaliyetlerini geliştirme adına okulların farklı cemaat/vakıf/derneklerin etkilerine açık bulunması ${ }^{40} \mathrm{da}$ önemli problem alanları olarak göze çarpmaktadır.

Ayrıca 2012 değişiklileri sonrasında bu okullarda zorunlu olarak okutulan derslere seçmeli derslerin de eklenmesiyle ${ }^{41}$ öğrencilerin ders yükü artmış, haftalık ders çizelgelerinde rehberlik çalışmaları ile sosyal etkinlikler için zaman kalmamıştır. ${ }^{42}$ Öğrenciler meslek kaygısıyla gelmedikleri için de özellikle meslek derslerini önemsememektedirler. ${ }^{43}$

Diğer yandan "branşlaşma imkânı bulunmayan meslek dersi öğretmenlerinin 24 farklı derse girme yükümlülüğünü taşıması, yöntem ve teknik, araç-gereç ve materyal, ölçme ve değerlendirme ve planlama içeren tüm eğitimsel faaliyetlerini olumsuz olarak" etkilemektedir. ${ }^{44}$ Ayrıca yetiştirilme sürecinde DKAB ve IHL meslek dersleri ayrımı yapılmaksızın uzmanlaşmadan eğitim alan öğretmenlerin bu durumu eğitsel açıdan niteliği ve verimliliğini etkileyebilmektedir. ${ }^{45}$ iHL'nde görev yapan öğretmenlerin büyük çoğunluğu, öğretmen yetiştirme süreçlerinin gözden geçirilmesi gerektiğini ${ }^{46}$ dile getirmektedirler.

IHL eğitiminin tasarımını oluşturan öğretim programları da eleştirilerin odağında yer almaktadır. 2017 yılında güncellenen programların eskilerinin tekrarı niteliğinde ve mesleğe ve yükseköğretime hazırlama açısından yetersiz olduğu, kazanımların ilgili derslerde uygulanamayacak kadar yoğun, değer ve becerilerin içerik ve kazanımlarla ilişkisiz olduğu ve dersler arasında bütünlük kurulama- 
dığı ${ }^{47}$ ifade edilmektedir. Meslek dersleri kitapları da içerik ve etkinlik örnekleri bakımından yetersiz bulunmaktadır. ${ }^{48}$

Sonuç olarak bazı kurumların yürüttükleri araştırmalar IHL eğitimini oldukça değerli ve kaliteli olarak niteler ${ }^{49}$ iken, bazı araştırmalarda bu okulların eğitimi problemli ${ }^{50}$ bulunmaktadır.

\subsection{STK Önerileri}

Çalışmanın ikinci ana temasını imam hatip liselerinde görülen problemlere ilişkin sivil toplum kuruluşlarınca sunulan öneriler oluşturmaktadır. İncelenen çalışmalarda imam hatip liselerine dair önerilerin okulların statüsü, mekânı, öğretim programı, öğretimin içeriği, dersler ile öğretmenler konusunda çeşitlendiği görülmektedir.

\subsubsection{Statü ve Eğitim Politikaları}

Bazı sivil toplum kuruluşu çalışmalarında toplum ve eğitimciler nezdinde İHL'lerin meslek lisesi mi genel lise mi olduğu konusundaki zihin karışıklığını gidermenin ${ }^{51}$ önemine dikkat çekilmektedir. Üstelik bu meselenin ivedilikle çözülmesi ve "bu okulların devlet nezdinde statüsünün netleştirilmesi" gerektiği ${ }^{52}$ vurgulanmaktadır. Devletin bu konudaki kararını netleştirmesinin ardından bu okullar hakkında toplumsal bir uzlaşı oluşturmak da gerekli görülmektedir.

Çalışmalarda imam hatip liselerinin meslek lisesi kapsamından çıkarılması önerisij ${ }^{53}$ bulunduğu gibi, bu okullara yönelik bazı üniversitelerin bünyesinde proje fakülteleri açılması ve bu bölümlere proje okullarından mezun olan öğrencilerin mülakat ile alımına imkân tanınması ${ }^{54}$ önerisi de yer almaktadır.

TiMAV, Imam Hatiplerde Mesleki Müfredat Raporu, 2017.

Aşlamacı, Öğrenci ve Öğretmenlerine Göre İmam-Hatip Liseleri.

Ertan Özensel vd., Türkiye'de Imam Hatip Lisesi ve Imam Hatipliler Algısı, (Türkiye İmam-Hatipliler Vakfi, 2012), 148.

Ebru Uzpeder vd., Gündelik Hayatta Laiklik Pratikleri, (İstanbul: Yurttaşılı Derneği, 2010).

Alpaydın, Geleceğin Türkiyesinde Eğitim, 122.

Türk Eğitim-Sen, Türkiye'de Din Eğitimi Çalıştayı.

TiMAV, Türkiye'de Din Ögrretimi Forumu. Geçmiş tarihlerde imam hatip liselerinin tam olarak meslek lisesine dönüştürülmesi (TÜSIAD 1990, 1997, 2006) önerisi ile Illahiyat fakülteleri için kaliteli öğrenciler yetiştiren seçkin kurumlara dönüştürülmesi ya da örgün kurumlarda seçmeli ders uygulamasına geçilmesi yoluyla bu okulların yükünün hafifletilmesi (TESEV, 2004; ERG, 2006) gibi öneriler de bulunulmuştur.

TiMAV, Imam Hatiplerde Mesleki Müfredat ve Program Çeşitliliği. 
Son yıllarda imam hatip liseleri özelinde dikkat çeken proje okulu uygulaması konusunda da dikkat çeken öneriler sunulmaktadır. Bunlar arasında "sanayi, meslek liseleri gibi teknik alanlarda imam hatip lisesi proje okulları ile dinî bilimler ağırlıklı program uygulayan imam hatip lisesi proje okulları açılması”, "Fen ve sosyal imam hatip liseleri projesinin sağlık, sanat, endüstri gibi alanlarda çeşitlendirilmesi", "Çok programlı liseler gibi aynı anda farklı programlar veren imam hatip liseleri oluşturulması” ${ }^{\prime 55}$, “Hafızlık eğitimi yapan özel statülü IHL okullarının açılması"56, yoğun olarak İslami eğitim almak isteyenler için ayrı bir program uygulanması ve iki farklı program esasına geçilmesi ${ }^{57}$ şeklinde program çeşitliliğinin arttırılmasına yönelik alternatif öneriler bulunmaktadır. DEM çalışması ${ }^{58}$ kapsamında görüşülen öğretmenlerin tamamına yakını mesleki alan programı hazırlanması gerektiği görüşünü paylaşmaktadırlar.

Ancak bu okulların planlanması ve yönetiminde objektif kriterlerin oluşturulması ve uygulanması, siyasi eğilimler doğrultusunda hareket edilmemesi, okulların açılışı aşamasında öğretmen yeterliği ve öğrenci potansiyeli analizlerinin yapılması, tespitlere göre yeni okul açmak yerine eskilerinin imkânlarının genişletilmesi yoluna gidilmesi ${ }^{59}$ gibi hususlara dikkat edilmesi önem taşımaktadır.

İmam hatip ortaokulu ve liselerinin -özellikle proje okullarının-açılmasında toplumun ihtiyaç ve beklentileri yanı sıra çok katmanlı/boyutlu analizler de yapılma$\mathrm{sı}^{60}$, bu okulların amaç, vizyon ve misyonları yeniden düzenlenmesi, genel eğitim içerisindeki konumunun belirlenmesi önem arz etmektedir. Proje okulları kadar, proje olmayan okulların da desteklenmesi ve geliştirilmesine çaba gösterilmesi' ${ }^{61}$ ve aralarındaki farklılıkların azaltılması ${ }^{62}$ gerektiği de vurgulanmaktadır.

“Herhangi bir okula yerleşemeyen düşük puanlı öğrencilerin otomatik olarak imam hatip liselerine yerleştirilmesinden vazgeçilmesi ve tercih dışı öğrenci yerleştirilmemesi" ${ }^{\prime 63}$ okulların kalitesi, öğrenci ve ailelerin ilgisi, olası mağduriyetlerin önlenmesi adına faydalı bir uygulama olarak önerilmektedir.

TIMAV, Imam Hatiplerde Mesleki Müfredat ve Program Çeşitliliği.

TiMAV, Türkiye'de Din Öğretimi Forumu.

Alpaydın, Geleceğin Türkiyesinde Eğitim.

Aşlamacı, Öğrenci ve Öğretmenlerine Göre İmam-Hatip Liseleri.

TiMAV, Imam Hatiplerde Mesleki Müfredat ve Program Çeşitliliği.

Türk Eğitim-Sen. Türkiye'de Din Eğitimi Çalıştayı.

TiMAV, Imam Hatiplerde Mesleki Müfredat ve Program Çeşitliliği.

Alpaydın, Geleceğin Türkiyesinde Eğitim, 122.

Türk Eğitim-Sen, Türkiye'de Din Eğitimi Çalıştayı. 
Din öğretiminin özelleştirilmesi meselesi de -dindarlardan laiklere- çok farklı kesimler tarafından paylaşılan bir çözüm olarak dikkat çekmektedir. TiMAV ${ }^{64}$ bu konuda ülkemizin gerçekleri ve diğer İslam ülkelerindeki uygulamaların dikkate alınması ve tartışılması önerisinde bulunmaktadır. Eğitim-Bir-Sen, "özel öğretim kurumu statüsünde imam hatip ortaokulu ve imam hatip lisesi açılmasını engelleyen hükümlerin kaldırılması" gerektiğini vurgulamaktadır. Öğretmenlerin çoğunluğu da özel imam-hatip okullarının açılmasına olumlu yaklaşmaktadır. ${ }^{65}$

\subsubsection{Okul Binaları}

İmam hatip kurumlarının mekânları da üzerinde durulan öneri konuları arasında yer almaktadır. Okul binası, mescidi, spor salonu, kütüphanesi, sineması ile ïHL Külliyesi sistemi yanı sıra öğrenciler için aktif öğrenme mekânları, sosyal etkinlik alanları, dil eğitimi için özel sınıflar, laboratuvarlar, sürekli açık zengin ve güncel kütüphaneler, mesleki pratik ortamları, hafızlık derslikleri, eğitimin okulun her bir köşesinde devam edecek şekilde tasarımlanan binalar ve öğretim iklimi, ders içeriğine göre uyarlanabilen öğrenci sayıları ve sınıfları, depreme dayanıklı, engelli dostu, sadece koridora açılan standart sınıf tasarımlarından oluşmayan yenilikçi binalar inşa edilmesi, kız ve erkek öğrenciler için ayrı binalar oluşturulması, yüksek öğrenci talebinde sınıfların yoğunluğunun artırılması yerine ek bina yapılması ${ }^{66}$, okul mimarisinin kurumların amaçlarına uygun olarak yapılandırılması $^{67}$ önerileri vurgulanmaktadır.

Ayrıca, ihtiyaca göre okul açılması, acil durumlar dışında yetersiz binaların kullanılmaması, okulun türü ve özelliğine -laboratuvar, atölye, spor alanları, konferans salonu, mescit gibi- özgün mekânların planlanması, israfa yol açacak mimari unsurlara yer verilmemesi, daha fazla öğrenci almak adına; laboratuvar, kütüphane ve uygulama mescit ve atölyelerin dersliğe dönüştürülmemesi ${ }^{68}$, Kamu okullarının İL/IHO dönüştürülmesi sürecinde "ölçülü, dengeleyici bir yasal düzenleme ve siyasi pratik uygulaması" ${ }^{\prime 69}$, okul sayılarının artırılmasından ziyade nitelikleri üzerinde durulması, okul binalarının doluluk oranlarının değerlendirilmesi, atıl kapasite tespiti halinde bu konuda gerekli tedbirlerin alınması ${ }^{70}$ gereğine de dikkat çekilmektedir.

TiMAV, Türkiye'de Din Öğretimi Forumu.

Aşlamacı, Öğrenci ve Öğretmenlerine Göre İmam-Hatip Liseleri.

TiMAV, "İmam Hatip Liseleri, Sorunlar ve Çözüm Önerileri" Çalıştayı Sonuç Raporu, (Konya: 2015).

Alpaydın, Geleceğin Türkiyesinde Eğitim.

Türk Eğitim-Sen, Türkiye'de Din Eğitimi Çalıştayı.

Zeytinoğlu, "Okuluma Dokunma," 61-62.

TEDMEM. 2018 Eğitim Değerlendirme Raporu, 213. 


\subsection{3. Öğretim Programları}

İmam hatip lisesi ve ortaokullarına yönelik bir diğer öneri alanı öğretim programları konusundadır. Öğretim programı oluşturulurken; bölgesel/mezhepsel farklılıkların, öğrencilerin gelişim basamakları, ihtiyaç ve beklentileri, sosyal ve ailesel özellikleri ve yaşadığı çevrenin, teknolojik gelişmelerin dikkate alınması, oluşturulma sürecinde ilgili sivil toplum kuruluşlarının ve okulların görüşlerinden faydalanılması, ezberleme yerine anlama ve uygulamanın amaçlanması, özellikle meslek derslerinin güncel konuları içermesi, konu başlıkları ile alakalı kitapların okunmasının sağlanması, uygulamaya yönelik ünitelerin ders saatlerinin diğer teorik derslere göre uzun tutulması ${ }^{71}$ gibi teklif ve tenkitler bulunmaktadır.

Ayrıca, Dinler Tarihi dersi müfredatı sadeleştirilmesi, kültür dersleri müfredatının meslek dersleriyle uyumunun sağlanması bilişsel kazanımların yanı sıra duyuşsal ve davranışsal kazanımlara da ağırlık verilen bir müfredat hazırlanması, konular arasındaki çelişkilerin giderilmesi, değerler konusunun gözden geçirilmesi, ortaokul seviyesinde zorunlu olan Peygamberimizin Hayatı dersi ile DKAB dersinin \%46 oranında benzeşen yapısının değiştirilmesi ve tematik yapısına tekrar kavuşturulması ${ }^{72}$ gerektiğine de dikkat çekilmektedir. Meslek dersleri öğretmenlerinin büyük çoğunluğu da meslek dersleri öğretim programlarının yeniden hazırlanması gerektiğini dile getirmektedir. ${ }^{73}$

Yabancı dil eğitim veren imam hatip liselerinin Müslüman nüfusu fazla olan yerlerin dillerinde eğitim vermesi, okullarda sunulan dil çeşitliliğinin arttırılması, fen bilimleri/ sosyal bilimler ağılıklı imam hatip liselerinde meslek derslerinin hafifletilmesi, -ortaokul düzeyinden başlayarak- sanatsal ve sosyal aktivitelerin artırılması, uluslararası öğrencilerin eğitim aldığı liselerin müfredatının yeniden hazırlanması ${ }^{74}$ da önerilmektedir. Okullarda seçmeli dersler yerine program türüne özel müfredat üzerinde çalışılması ve programların öğrencilerin ihtiyaçları doğrultusunda çeşitlendirilmesi de ${ }^{75}$ önerilmektedir. 


\subsubsection{Meslek Dersleri}

İncelenen çalışmalarda îH/iHO derslerine yönelik öneriler de bulunmaktadır. "Zorunlu olarak okutulan ortak ders saatlerinin genel ortaöğretim kurumlarına paralel olarak azaltılması", "10. sınıf seçmeli derslerinin 10 saatten 12 saate çıkartılması"76 önerisinde bulunulmaktadır. Ayrıca, "sosyal derslerin ortaokulda; sayısal derslerin ise lisede ağırlıkla verilmesi", "Temel Dini Bilgiler dersinin sadece ortaokul programında yer alması", "lisede seçmeli dinî ilimler dersleri sunulması", "ortaokulların ilk yılının Arapça hazırlık ya da hafızlık eğitimine ayrılması", "Kur'an-ı Kerim ve mesleki Arapça derslerinin tüm sınıflarda haftada ikişer saat düzenlenmesi" ${ }^{177}$ ve niteliklerinin arttırılması ${ }^{78}$ teklifleri sunulmaktadır.

Bunun yanı sıra öğretmenler tarafından programda yer alan meslek derslerinin oranının artırılması, lise 1 ve 2 . sınıflarda meslek derslerine daha fazla yer verilmesi ve Tasavvuf dersinin eklenmesi gerektiği dile getirilmektedir.79 "Hadis ve Tefsir derslerinin lise 3. Sınıf, Fıkıh ve Hitabet derslerinin ise lise 2. sınıf seviyesine alınması"80, "9. Sınıf Kur'an dersinin 6 saate çıkarılması, 9. sınıf yabancı dil dersinin 4 saate düşürülmesi, 9. sınıf Temel Dini Bilgiler dersi yerine süresi arttırılarak fıkıh dersi konulması, mesleki derslerin ilk yıllarda daha yoğun verilerek son yıllara doğru azaltılması, ortak sayısal derslerin 10. Sınıf itibariyle seçmeli hale getirilmesi, son sınıfta ders saatlerinin kısaltılması"81 gerektiği vurgulanmaktadır.

Bunlara ilaveten lise düzeyinde "Din Psikolojisi" ve "Din Sosyolojisi" derslerinin verilmesi, "Mesleki Hitabet" dersinin "Dinî Illetişim ve Mesleki Hitabet" olarak güncellenmesi ${ }^{22}$, "Peygamberler Tarihi, İslam coğrafyası, İslam Bilim Tarihi” derslerinin eklenmesi ${ }^{83}$, "Islam Felsefesi" dersinin seçmeli olarak sunulmas ${ }^{84}$ da teklif edilmektedir.

Arapça, Kur'an-ı Kerim, Fıkıh, Hadis, Tefsir, Dinler Tarihi, Siyer derslerinin içeriklerine yönelik öneriler de detaylandırılmıştır. 
Arapça ders içeriklerinin mesleki metin ağırlıklı olarak hazırlanması, 30. Cüzün tamamının ve Fetih Suresinin ezber listesine eklenmesi, ezberlenen namaz surelerinin meallerinin öğretilmesi, derslerde konuların örneklerle, dünya gerçekleri ve günlük hayattaki meselelerle irtibatlandırılması, hadis ve tefsir metinlerine ağırlık verilmesi, hadis ezberlerinin performans ödevi olarak değerlendirilmesi, ders kitaplarının z-kitap şeklinde hazırlanması, sunulan tefsir kaynaklarının çeşitlendirilmesi, uygulama gerektiren derslerde görsel anlatım gerçekleştirilmesi ${ }^{85}$ önerileri sunulmaktadır.

Ayrıca, Hadis dersinde öğrencilerin anlam ve kavram dünyalarını dikkate alan ve günlük hayatta karşılaşılan ve tartışılan sorunlara cevap veren hadislerin öncelikli olması, Dinler Tarihi dersinde diğer dinleri İslam dini ile karşılaştıran bir yöntemin benimsenmesi, yeni din hareketlerine yer verilmesi, Siyer dersinde Peygamberimizin insani özelliklerine vurgu yapılması, dersin sosyal tarih metoduyla aktarılması ve okuma parçalarında sahabelerin hayatına yer verilmesi, Tefsir, Hadis, Fıkıh, Akaid dersleri konularının birbirleriyle senkronize edilerek anlatılması, Tefsir dersinde tarih ve usul bilgisi yanı sıra ayetlerin anlaşılmasının öncelenmesi, Fıkıh dersinde konuların detaylarının ezberlenmesinden ziyade, fıkhi hükümlerin mantığının anlaşılması, araştırma ve sorgulama yapılması, güncelle bağının kurulması $^{86}$ gereği vurgulanmaktadır.

Ortaokul düzeyinde Peygamberimizin Hayatı dersinin klasik kronolojik siyer anlayışı ile aktarılmaması, içerikte tematik ve hayatın içinde bir Peygamber örneği sunulması, Temel Dini Bilgiler dersinde, öncelikle temel düzeyde bir usul bilgisi verilmesi, içeriğinin ahlaki konulara kaydırılması ${ }^{87}$ "ilahiyat tercihi yapacak öğrencilere üniversiteye girişte mesleki derslerine ait sorular sorulması"88 gibi farklılıkların oluşturulmasının derslere katkı sağlayacağı düşünülmektedir.

Kur'an- Kerim ve Arapça dersleri mesleki eğitimde özel öneme sahiptir. "Kur'an-ı Kerim dersi için öğrenci seviyelerinin belirlenmesi ve sınıfların bu verilere göre oluşturulması, ses temelli yöntemler ve işitsel tekniklerin kullanılması, tecvit eğitimine erken başlanması, Diyanet İşleri Başkanlığı ile iş birliği yapılması"89,

TiMAV, Imam Hatip Liseleri, Sorunlar ve Çözüm Önerileri. TiMAV, Imam Hatiplerde Mesleki Müfredat ve Program Çeşitliliği. TiMAV, Imam Hatiplerde Mesleki Müfredat ve Program Çeşitliliği.

TiMAV, Imam Hatiplerde Mesleki Müfredat ve Program Çeşitliliği; Türk Eğitim-Sen. Türkiye'de Din Eğitimi Çalıştayı.

TiMAV, Imam Hatiplerde Mesleki Müfredat ve Program Çeşitliliği. 
“Kur'an-ı Kerim derslerinde sınıf sayılarının ikiye bölünüp iki ayrı hocanın derse girmesinin sağlanması" ${ }^{\prime 90}$ teklif edilmektedir.

Arapça dersi için "derste yeni yöntemler kullanılması, ölçme-değerlendirmenin kaliteli olarak yapılması, dil kitaplarının anlaşılır ve görsel açıdan yeterli seviyede olması, yardımcı kitaplar içermesi, Arap dili ve edebiyatı bölümü mezunu öğretmenler yanı sıra yabancı öğretmenlerin ders vermesinin sağlanması"91 önerilmektedir. Ayrıca, "sınıflar oluşturulurken öğrenci seviyelerinin dikkate alınması, gramerin azaltılarak, okuma, yazma, anlama ve günlük dilde kullanma becerilerinin ön plana çıkarılması, Kur'an-ı anlamaya yönelik bir dil eğitimi verilmesi, dersler için dil laboratuvarları oluşturulması, imam hatip lisesine geçiş için kullanılmak üzere TEOG sınavında Arapçaya da yer verilmesi"92 de dile getirilen öneriler arasında yer almaktadır.

Çağın ihtiyaçları doğrultusunda çok yönlü, iletişimi güçlü ve örnek davranışlara sahip din görevlilerinin yetiştirilmesi için bu becerileri edindirecek yeni dersler eklenmesi gerekliliğine ${ }^{93}$ ve derslerin içerikleri kadar okul kültürü yoluyla moral ve değer aktarımının önemine ${ }^{94}$ de dikkat çekilmektedir.

\subsection{5. Öğretmenler}

İncelenen çalışmalarda IHL öğretmenleriyle ilgili özel öneriler de sunulmaktadır. Öğretmenlerin öğrencilerle birlikte sosyal ve kültürel faaliyetlere daha fazla katılması, ders dışı etkinliklere teşvik edilmesi, teknolojik ve güncel gelişmeleri takip etmesi, aynı kurumda 8 yılı dolduran öğretmenlerin performansları ölçülerek rotasyonla yer değiştirmesi, öğretmenlerin periyodik olarak hizmet içi eğitimden geçirilmesi, açık öğretim mezunlarına öğretmenlik verilmemesi, yükseköğrenimde staj uygulanmasının 2 yıla yayılması, İlahiyat Fakültesi programlarının güncellenerek mesleki ve formasyona yönelik uygulamaların artırılması, öğretmen yetiştirme sürecinde IHL müfredatını gerçekleştirebilecek beceriler kazandırılması, Kur'an dersine giren öğretmenlerin tashihi huruf kurslarına katılması ${ }^{95}$ ve meslek derslerinde branşlaşma ${ }^{96}$ gibi hususların önemine dikkat çekilmektedir. 
Kur'an- Kerim ve Arapça öğretmenlerinin yeni öğrenme teknikleri konusunda eğitime tabi tutulmaları ve Kur'an-ı Kerim öğretmenliği ayrı branş haline getirilmesi, yükseköğretim düzeyinde özel öğretim yöntemleri içerisine Arapça öğretimi, Kur'an öğretimi gibi alanların dahil edilmesi, proje okulunda görev yapacak öğretmen ve idarecilerin ciddi bir oryantasyon eğitiminden geçirilmesi, başarılı öğretmenleri proje okullarında çalışmaya yöneltecek -hizmet puanı, ek ders, ödül ve taltif gibi- bir düzenleme yapılması, en başarılı öğretmenler kadar mevcut kadro ile uyumlu, proje okulunun vizyon ve misyonuna göre çalışabilecek vasat başarıdaki öğretmenlerin de tercih edilebilmesi, proje okulları için öğretmen seçilirken diğer okullar öğretmensiz bırakılmaması ve tüm nitelikli öğretmenler alınmaması ${ }^{97}$, İHL öğrencilerinin dil becerilerinin geliştirilmesi konusundaki çabaların materyal ve kaynak desteği ve yaz eğitimleri gibi ek imkânlar ile sınırlandırılmayarak eğitimi gerçekleştirecek öğretmenlerin yeterliklerinin desteklenmesi98 de önemli görülmektedir.

\section{Tartışma}

Araştırma kapsamında ele alınan sivil toplum kuruluşu çalışmalarında gerek imam hatip lisesi/ortaokulları gerekse öğrenci sayılarındaki niceliksel artışa dikkat çekilmiştir. Bununla birlikte öğrenci sayılarında son yıllarda düşüş yaşandığı belirtenler de bulunmaktadır. Nitekim imam hatip lisesi ve ortaokullarında bulunan öğrenci oranları tüm sisteme oranladığında $\% 9^{99}$ gibi bir yüzdeye tekabül etmektedir ki bu oranın endişe verici bir boyutta olduğu söylenememektedir. Bu bağlamda asıl vurgulanması gereken meselenin öğrenci sayılarından ziyade eğitimin kalitesi olduğu düşünülmektedir.

İncelenen çalışmalarda öğrenci/mezun niteliklerinin de mercek altına alınmış olduğu tespit edilmiştir. Nitekim din eğitimi alan yazında da öğrenci sayılarından ziyade eğitimin niteliği üzerinde durulmaktadır. Eğitimin niteliğini değerlendirme ölçütleri ise üniversite sınavındaki başarılarla ölçülmektedir. Yine çalışmalarda, 
imam hatip liselerinin mesleki din eğitimi kurumları olması dolayısıyla, akademik eğitim nitelikleri ile birlikte dini eğitim nitelikleri de değerlendirilmektedir.

STK raporlarında da vurgulandığı üzere, imam hatip liselerinin akademik ve dinî eğitimlerine, yoğun müfredatlarına, meslek dersleri ve öğretim programlarından ders kitaplarına, dil öğretme becerilerinden öğrencilerini üniversiteye hazırlamaya uzanan nitelikleri, plansız ya da ihtiyaç gözetilmeksizin yapılanmalarından akademik başarısı düşük öğrencilerin direkt kayıtlarına uzanan çeşitlilikte ilgi maddeleriyle gündeme alınması gerekmektedir.

Bütün olumlu nitelikleriyle birlikte imam hatip liselerinde yetişen öğrenciler diğer liselerle akademik açıdan karşılaştırıldığında ${ }^{100}$ başarılı görülmemektedirler. Ancak bu problemin imam hatip liselerine özel olmadığı, eğitim sisteminin genelinde görüldüğüne de işaret edilmelidir. Eğitim sisteminin bir parçası olarak imam hatip liselerinin bu yapının genel problemlerini yansıttığına dikkat çekilmelidir. Bununla birlikte imam hatip liseleri özelinde yansıyan problem alanları da bulunmaktadır.

Meslek lisesi olarak planlanmış olmakla birlikte bu kurumlara sadece dinî bilgilerini arttırmak ve -çok yüksek oranda ilahiyat dışında- üniversite eğitimi almak için gelen öğrenciler meslek derslerinden dolayı oldukça zorlanmaktadır ve verilen eğitimi ağır bulmaktadırlar. ${ }^{101}$ Ayrıca üniversiteye gidememekten endişe etmektedirler. ${ }^{102}$ IHL öğrencileri de okullarının eğitim kalitesini orta düzeyde nitelemekte, aldıkları eğitimin üniversiteyi kazanmaya katkı sağlamayacağını yüksek bir oranla (\%75) ifade etmektedirler. ${ }^{103}$ Son yıllarda akademik başarısı yüksek bir

100 Fen liseleri, Sosyal bilimler liseleri, Anadolu liseleri gibi.

101 Ömer Yunus Ece, "Anadolu Imam Hatip Lisesi Eğitim Programına Yönelik Öğrenci ve Öğretmen Görüşleri (Kartepe IIlçesi Örneği)” (Yüksek Lisans Tezi, Sakarya Üniversitesi, 2018); Şahin Çalışkanoğlu, "Imam-Hatip Lisesi Öğrencilerinin Sorun Ve Beklentileri (Çorum Örneği)" (Yüksek Lisans Tezi, Hitit Üniversitesi, 2018); Korkmaz, "İmam Hatip Lisesi Öğrencilerinin Bu Okulu Tercih Süreçleri: Nasıl? ve Neden?" 100. Yılında İmam Hatip Liseleri, ed. Recep Kaymakcan vd.. İstanbul: Değerler Eğitimi Merkezi, 2015; Kanburoğlu, Betül Ü, “Popüler Kültür-Din Eğitimi İlişkisi: İmam Hatip Liseleri Örneği" (Yüksek Lisans Tezi, Marmara Üniversitesi, 2011; Tuncay Karateke, "İmam-Hatip Lisesi Öğrencilerinin Sorun ve Beklentileri (Batman İli Örneği)". (Yüksek Lisans Tezi, Fırat Üniversitesi, 2010).

102 Ece, "Anadolu Imam Hatip Lisesi"; Erkan Altıntaş, "Öğrencilerde Imam-Hatip Lisesi Algısı (Batman Örneği)”. (Yüksek Lisans Tezi, Hitit Üniversitesi Sosyal Bilimler Enstitüsü, 2016); Kanburoğlu, “Popüler Kültür".

103 Ertan Özensel ve Aydemir, Mehmet Ali. Türkiye Imam Hatip Lisesi Öğrenci Profili Araştırması (Temel Sorunlar, Beklentiler ve Değer Yapıları). (Türkiye İmam-Hatipliler Vakfı, 2014). 
okula yerleşemediği için gelen öğrencilerin sayısının yükseldiğine, öğrencilerin yüksek bir puan aldıkları takdirde imam hatip liselerini tercih etmeyebildiklerine ${ }^{104}$ de dikkat çekilmektedir.

Türkiye derecesi yapan pek çok öğrencisi bulunan Kartal AiHL gibi okullar istisna tutulursa İHL mezunu öğrencilerin üniversiteye yerleşme oranlarının düşük olduğu ifade edilebilir. Oranlar \%5 ile 10 arasında değişmektedir. 2018 yılı için üniversiteye yerleşme oranı \%14,9 iken, Açı̈öğretim fakültesine yerleşenler dahil edildiğinde bu oran \%36 olmaktadır. ${ }^{105}$ Bununla birlikte bu oranlar bazı okullar için oldukça farklılaşmaktadır. Örneğin, Ankara Tevfik ileri AiHL için mezunlarını üniversiteye yerleştirme oranı \%74'tür. Ancak bu başarıların ülke çapındaki imam hatip liselerinin çoğunluğu için gerçekleşmesi zor görünmektedir. Bununla birlikte Erdem 2 gibi projeler hayata geçirilerek okullar arası iş birliği modeliyle okullar arasındaki başarı farklarının azaltılması hedeflenmektedir. ${ }^{106} 2020$ yılı sonuçları üniversiteye yerleşme konusunda gelişme gösterildiğini ortaya koymaktadır. Illk 100 ve ilk 1.000 gibi başarı dilimlerinde yer alan imam hatip mezunu öğrencilerin artışı dikkat çekmiştir. 2020 YKS sonuçlarında örgün lisans programları (lisans+önlisans) için genel başarı ortalaması \%29, Açıköğretim dahil edildiğinde \%38 olmuştur. ${ }^{107}$ Uygulanmakta olan projelerin sonuçlarının değerlendirilmesi için gelecek yıllarda da çalışmalar yürütülmesi önem taşımaktadır.

Diğer yandan din görevlisi yetiştirme amacında olan -daha doğrusu olduğu varsayılan- bu kurumları tercih eden öğrenciler din görevlisi olmak istememektedirler. Öyle ki din görevliliğini tercih oranları bazı çalışmalarda \%3,5'a kadar düşmektedir. Çalışmalarda en fazla \%37, ortalama \%10 gibi bir oranda din görevliliğinin talep edildiği görülmektedir. Velilerin de çocuklarının din görevlisi

104 Şuayip Özdemir ve Tuncay Karateke, "Öğrencilerin İmam Hatip Liselerini Tercih Etme Nedenleri (Elazığ Örneği)," OMUIFD: Ondokuz Mayis University Review of the Faculty of Divinity, 45 (2018); Zeynep Kaya, "Illahiyat Dışında Lisans Eğitimi Planlayan İmam-Hatip Lisesi Öğrencilerinin Meslek Dersleri İle İlgili Değerlendirmeleri Üzerine Nitel Bir Araştırma," İslam Medeniyeti Araştırmaları Dergisi, 3/1 (2018).

105 Üniversiteye yerleşme sonuçları Sosyal Bilimler liseleri için \% 67, Fen liseleri için \% 52, Öğretmen lisesi için \% 43, Anadolu lisesi için, \% 29, diğer liseler \% 8, Teknik ve meslek lisesi mezunları için \% 4 oranındadır. "2019 Yükseköğretim Yerleştirme Oranları", erişim 13 Ekim 2020, https:// www.dogrulukpayi.com/bulten/universiteye-yerlesmede-hangi-okullar-daha-basarili.

106 "Anadolu İmam Hatip Liselerinden YKS'de Büyük Başarı", erişim 20 Ekim 2020, https://www. aa.com.tr/tr/egitim/anadolu-imam-hatip-liselerinden-yksde-buyuk-basari-/1925852.

107 "2020 YKS Yerleştirme Sonuçlarına İlişkin Sayısal Bilgiler", erişim 20 Ekim 2020, https://dokuman.osym.gov.tr/pdfdokuman/2020/YKS/sayisalbilgiler26082020.pdf. 
olmasını tercih etmedikleri çalışmalara yansımaktadır. ${ }^{108}$ Dinî yükseköğretim almak tercihi olmayan öğrencilerin imam hatip liselerine yönelmesinin olası pek çok sebebi bulunmaktadır. Bu sebepler arasında; öğrencilerinin dinî bilgileri öğrenme isteği, bu okullarla özdeşleşen ahlaki nitelikler, öğrencilerine kazandırdığı dinî ve milli değerler, okulun dinî tercihlere uygun ortamı/iklimi, kıyafet konusundaki tutumları, karma olmayan sınıf/okul düzeninin bulunduğu düşünülmektedir. ${ }^{109}$ Bu eğitim kurumunun tercihinde eğitim kalitesi ön planda bulunmamakla birlikte proje okullarıyla birlikte bu tutum da değişmektedir. ${ }^{110}$

İncelenen STK çalışmalarında eleştirilen noktalardan birisi de son yıllarda öğrencilerin IHO/IHL sınav sisteminin bir sonucu olarak istek dışı olarak yerleştirilmeleridir. Bu vurgular kendi tercih ve isteğiyle bu okullara kaydolan çoğunluğun göz ardı edildiği izlenimini uyandırmaktadır. İstek dışı kayıtlar hakkındaki veriler, literatürdeki çalışmalarda öğrencilerin tercihlerinin ön plana çıktığı şeklindeki verilerle farklılaşmaktadır. Bu okulları tercihte en büyük etkinin, oranları araştırmalara göre değişmekle birlikte, öğrencilerin kendi istekleri ve ailelerinin yönlendirmesi olduğu ortaya konulmaktadır. ${ }^{111}$

108 Çalışkanoğlu, "Imam-hatip lisesi öğrencilerinin"; Ece, "Anadolu Imam Hatip Lisesi"; Altıntaş, "Öğrencilerde Imam-Hatip"; Ömer Faruk Çelik, "Katsayı Uygulamasının Kaldırılması sonrasında Imam Hatip Lisesi öğrencilerinin davranış, tutum ve özellikleri (Gaziantep örneği)". (Yüksek Lisans Tezi, Uludağ Üniversitesi, 2016); Korkmaz, "İmam Hatip Lisesi”; İren Özgür, İmam Hatip Okulları Inanç, Siyaset ve Eğitim. (İstanbul: Kitap Yayınevi, 2015), 66; Özensel ve Aydemir, "Türkiye Imam Hatip Lisesi Öğrenci Profili".

109 Ahmet Ünsür, Kuruluşundan Günümüze Imam-Hatip Liseleri (İstanbul: Ensar Neşriyat, 2005), 221; Kanburoğlu, "Popüler Kültür-Din Eğitimi İlişkisi"; Özensel, Akın ve Aydemir, "Türkiye'de Imam Hatip Lisesi"; Engin Aslanargun, Abdurrahman Kılıç, ve Sinan Bozkurt, "Parental Expectation and Religious Education in State Schools in Turkey: The Case of Imam Hatip High Schools," International Journal of Instruction 7.1 (2014); Figen Kervankaya, "Imam Hatip Liselerinde Arapça Öğretimi Üzerine Bir Değerlendirme," Eskişehir Osmangazi Üniversitesi Illahiyat Fakültesi Dergisi 1 (2014); Özensel ve Aydemir, "Türkiye Imam Hatip Lisesi Öğrenci Profili"; İsmail Çağlar, "Anadolu'dan Viyana'ya İmam-Hatipler: Modernleşme, Diaspora ve Eleştiri," Sakarya University Journal of Education 5.1 (2015); Özdemir ve Karateke, "Öğrencilerin İmam Hatip Liselerini”; Çalışkanoğlu, "Imam-hatip lisesi öğrencilerinin".

110 Özdemir ve Karateke, "Öğrencilerin İmam Hatip Liselerini".

111 Ece, "Anadolu Imam Hatip Lisesi"; Özdemir ve Karateke, "Öğrencilerin İmam Hatip Liselerini"; Aşlamacı, Öğrenci ve Öğretmenlerine Göre İmam-Hatip Liseleri; Çelik, "Katsayı uygulamasının kaldırılması"; Ayşe Vural, "İmam-Hatip Lisesi Son Sınıf Öğrencilerinin Mesleki Yeterlilik Algısı"(Yüksek lisans tezi, Ondokuz Mayıs Üniversitesi,2016); Altıntaş, "Öğrencilerde Imam-Hatip"; İbrahim Aşlamacı ve Emrah Eker, "İmam-Hatip Lisesi Öğrencilerinin Okul Aidiyet ve Dinî Tutum Düzeyleri Arasındaki İlişkinin İncelenmesi," Değerler Eğitimi Dergisi 14.32 (2016); Altıntaş, Erkan. "Öğrencilerde Imam-Hatip Lisesi Algısı (Batman Örneği)" (Yüksek Lisans Tezi, Hitit Üniversitesi Sosyal Bilimler Enstitüsü, 2016); Korkmaz, "İmam Hatip Lisesi Öğrencilerinin”; Özensel ve Aydemir, "Türkiye Imam Hatip Lisesi"; Karateke, "Imam-Hatip Lisesi Öğrencilerinin". 
Günümüzde imam hatip liselerinin yapısında da bir çeşitlenme yaşanmaktadır. Fen ya da sosyal bilimler ağırlıklı okullar, uluslararası okullar ve sanat ve spor okulları açılmış durumdadır. Bu okullardaki öğretim içeriği de farklılaşmaktadır. İmam hatip liselerinin öğretim içeriğindeki çeşitlenmeyle birlikte halen din görevlisi yetiştirme ve yükseköğrenime öğrenci yetiştirme amaçlarını birlikte yürütmeye devam ettikleri görülmektedir. Bu bağlamda sosyolojik ve pedagojik anlamdaki değişimlerin okulların ilk olarak 1924'te ortaya konulan amaçlarına yansımadığı ifade edilebilir. Bu durum, imam hatip liselerinin statüsünün tartışıması gerekliliğine işaret etmektedir.

STK çalışmalarında olduğu gibi literatürde de imam hatip liselerinde yaşanan problemlere yönelik çözüm önerileri sunulmaktadır. Bu okullarda öğrenim gören öğrenciler için dinî yüksek öğretim ve diğer fakülteleri tercih edenlere yönelik ayrı programların gündeme getirilmesi ve çeşitlendirilmesi ${ }^{112}$ gündeme taşınmaktadır. Öğrenciler, okullarının kendilerini üniversiteye hazırlamadığını dile getirmektedirler. ${ }^{113}$ Bu bağlamda özellikle son sınıfta yoğun olarak verilen meslek derslerinin de alt sınıflara alınması ${ }^{114}$ öğrencilerin ve okul müdürlerinin talebi olarak dile getirilmektedir.

Sivil toplum kuruluşlarının öneri detaylarında da görüldüğü üzere öğretim programlarına dair öneriler de sunulmuştur. İmam hatip lisesi meslek dersleri öğretim programlarında 2018 yılında gerçekleştirilen son güncellemeyle birlikte bu önerilerin ne ölçüde uygulamaya geçirildiğinin de tespit edilmesi gerekmektedir.

En çok zorlanılan ve öğretiminde yetersiz kalınan ders olarak ortaya çıkan Arapça ve Kur'an-ı Kerim dersleri ${ }^{115}$ için gerekli adımların atılması da önem taşımaktadır. Ayrıca mesleki nitelik kazandırması için staj uygulaması da ${ }^{116}$ talep edilmektedir. İsim yapmış bazı AïHL ve proje okulları dışında kalan okulların genelinde yoğun bir ders programıyla eğitim alan IHHL öğrencileri akademik açıdan yetersiz kalabilmektedir. Dolayısıyla imam hatip liselerini -tercih sebebi olan okul iklimini

112 Ece, "Anadolu İmam Hatip Lisesi"; İbrahim Aşlamacı, "İmam Hatip Liselerindeki Din Eğitiminin Niteliği Ille İlgili Sorunlar: Okul Yöneticilerinin Görüşlerine Dayalı Nitel Bir Araştırma," Electronic Turkish Studies 12.10 (2017).

113 Korkmaz, "'Iİmam Hatip Lisesi Öğrencilerinin”.

114 Kaya, "Illahiyat Dışında Lisans Eğitimi”; Aşlamacı, "İmam Hatip Liselerindeki Din Eğitiminin Niteliği”.

115 Aşlamacı, Öğrenci ve Öğretmenlerine Göre İmam-Hatip Liseleri, 322.

116 Ömer Alper Karasubaşı, Akın Uğur ve Nail Yıldırım. "Öğrenci ve Mezunlarının Perspektifinden İmam Hatip Liselerinin Değerlendirilmesi," Değerler Eğitimi Dergisi 18.39 (2019): 65-105. 
göz ardı etmeksizin- hem dinî eğitimleri hem de akademik eğitimleri açısından tartışmaya ihtiyaç bulunmaktadır.

Ayrıca sivil toplum kuruluşları tarafından dile getirilen ve literatürde de yer verilen ortak noktalardan biri de son dönemde artan günübirlik kararlar ve yetersiz planlamayla okul açma ${ }^{117}$ eğiliminin bırakılması gerekliliği ${ }^{118}$ hakkındadır. Bu konunun saha çalışmalarıyla ele alınması önem taşımaktadır.

Son yıllardaki araştırma raporları incelendiğinde, özellikle bu okullara yönelik misyonlarıyla kurumlaşan sivil toplum kuruluşlarının imam hatip liseleri hakkında detaylı çalışmalar yürüttükleri görülmektedir. İmam hatip liselerindeki müfredat çalışmaları konusunda Türkiye İmam Hatipliler Vakfı (TIMAV)'nın gayretleri ve çalışmaları dikkat çekmektedir. Bu husus imam hatip misyonuyla kurumsallaşan bu sivil toplum kuruluşunun amacına dönük etkili çalışmalar yaptığını ortaya koymaktadır. İmam hatip liselerine dair verileri detaylı olarak ele alan bir diğer kuruluş ise Türk Eğitim Derneği (TED) olmuştur. Bununla birlikte bir asra yakın bir geçmişe sahip olan bu köklü kurumlar hakkında alan araştırmasına dayalı çaIışmaların azlığı oldukça düşündürücüdür. İmam hatip liselerinde son 10 yılda yoğunlaşan fiziksel ve teknolojik katkılara rağmen eğitimin kalitesinin düştüğü yönündeki iddialar ya da bu düşüşün olası nedenlerinin, spekülasyonların ötesinde araştırma sonuçları doğrultusunda ortaya konulması önem arz etmektedir.

\section{Sonuç}

Sivil toplum kuruluşlarının eğitim ve din eğitimi alanında devlete bir paydaş olarak katkıda bulunma potansiyeli oldukça yüksektir. Bu çalışmada da ortaya koyulduğu üzere Türkiye'deki sivil toplum kuruluşlarından bazıları bu konuda çaba göstermektedirler. Akademisyenler ile iş birliği içerisinde gerçekleştirilen projeler, değerlendirme ve öneri çalışmaları neticesinde oldukça verimli araştırmalar sunulabilmektedir. Ancak bu tarz çalışmaların oldukça düşük kaldığı vurgulanmalıdır. Bu anlamda eğitimin bir paydaşı olarak Türkiye'deki sivil kuruluşlarının bu yöndeki çalışmalara yoğunlaşması ile topluma sunacağı katkıları arttıracağı düşünülmektedir.

117 Ömer Faruk Çelik, "Katsayı uygulamasının kaldırılması sonrasında Imam Hatip Lisesi öğrencilerinin davranış, tutum ve özellikleri (Gaziantep örneği)". (Yüksek Lisans Tezi, Uludağ Üniversitesi, 2016).

118 Karasubaşı, "Öğrenci ve Mezunlarının Perspektifinden”. 
Çalışma verileri imam hatip liselerinin daha önce uygulanan katsayı probleminin olumsuz etkilerini hızla telafi ettiğini ortaya koymaktadır. Okul ve öğrenci sayılarında gözlenen keskin düşüşlerin yerini keskin olmasa da istikrarlı bir yükseliş almış görünmektedir. Bu durumun muhtemel pek çok sebebi bulunabilmektedir. Ancak bu yönelimin aile ve öğrencilerin yükseköğretime devam konusundaki taleplerinin açık bir sonucu olduğu ortadadır. Son yıllardaki bu dalgalanma, bu okulların tercih sebeplerinin imam hatip kurumuyla dolaylı ilgisini de göstermektedir. Şöyle ki öğrenci seçme sisteminde kısıtlamalar söz konusu olmadığında yönelim yüksek iken, kısıtlamalarla düşüşe geçmesi, problemin okullardan kaynaklanmadığını ortaya koymaktadır.

Şüphesiz imam hatip liselerini odağa alarak eğitimin niteliğini değerlendirme çalışmaları genel olarak eğitim sisteminin mevcut kalitesi ve problemlerinden soyutlanarak değerlendirilememektedir. Türk eğitim sisteminin örgün kurumlarından biri olarak imam hatip liseleri bu yapının bir parçasını oluşturmaktadır. İmam hatip liseleri bağlamındaki tartışmalar bir anlamda eğitim sistemindeki problem alanlarına da işaret etmektedir. İmam hatip liselerini bağlı bulunduğu eğitim sistemi yapısından çekip alarak değerlendirmek bazı durumlarda taraflı ve objektif olmayan yorumlar yapılabilmesine yol açabilmektedir.

İmam hatip liselerinin özellikle dini eğitimlerinin değerlendirme kapsamına alınmaması ve sadece akademik başarılar üzerinden yorumlanması oldukça düşündürücüdür. İsim yapmış bazı AïHL ve proje okulları dışında kalan okulların genelinde yoğun bir ders programıyla eğitim alan IHL öğrencileri, akademik açıdan yetersiz kalabilmektedir. Dolayısıyla imam hatip liselerini -tercih sebebi olan okul iklimini göz ardı etmeksizin- hem dinî eğitimleri hem de akademik eğitimleri açısından geliştirmeye intiyaç bulunmaktadır. Milli Eğitim Bakanlığı bünyesindeki Din Öğretimi Genel Müdürlüğü son dönemlerde imam hatip liselerinde kalitenin artırımasına yönelik çalışmalarına hız kazandırmış durumdadır. Bu çalışmalarının sonuçlarının analiz edilmesi daha sağlıklı değerlendirmeler yapılabilmesini sağlayacaktır.

\section{Kaynakça}

Alpaydın, Yusuf. Geleceğin Türkiyesinde Eğitim. İstanbul: ILKE İlim Kültür Eğitim Vakfı, 2018.

Altıntaş, Erkan. "Öğrencilerde İmam-Hatip Lisesi Algısı (Batman Örneği)". Yüksek Lisans Tezi, Hitit Üniversitesi, 2016.

Aslanargun, Engin, Abdurrahman Kılıç, ve Sinan Bozkurt. "Parental Expectation and Religious Education in State Schools in Turkey: The Case of Imam Hatip High Schools". International Journal of Instruction 7/1 (2014): 135-150. 
Aşlamacı, İbrahim ve Emrah Eker. "İmam-Hatip Lisesi Öğrencilerinin Okul Aidiyet ve Dinî Tutum Düzeyleri Arasındaki Iliş̧inin Incelenmesi". Değerler Eğitimi Dergisi 14/32 (2016): 7-38.

Aşlamacı, İbrahim. Öğrenci ve Öğretmenlerine Göre İmam-Hatip Liseleri Profiller, Algılar, Memnuniyet, Aidiyet. İstanbul: DEM, 2017.

Aşlamacı, İbrahim. "İmam Hatip Liselerindeki Din Eğitiminin Niteliği Ile İlgili Sorunlar: Okul Yöneticilerinin Görüşlerine Dayalı Nitel Bir Araştırma". Electronic Turkish Studies 12/10 (2017): 49-80.

Bahçekapılı, Mehmet. Türkiye'de Din Eğitiminin Dönüşümü (1997-2012). ILKE Ilim Kültür Eğitim Derneği, 2014. Erişim https://www.yekder.org/images/yayinlar/tuded_1018.pdf

Çağlar, İsmail, "Anadolu'dan Viyana'ya İmam-Hatipler: Modernleşme, diaspora ve eleştiri". Sakarya University Journal of Education 5/1 (2015): 81-94.

Çaha, Ömer. Sivil Toplum Sivil Topluma Karşı. İstanbul: Mana Yayınları, 2017.

Çakır, Ruşen, İrfan Bozan ve Balkan Talu. İmam Hatip Liseleri: Efsaneler ve Gerçekler. İstanbul: TESEV Yayınları, 2004. Erişim https://www.tesev.org.tr/tr/research/imam-hatip-liseleri-efsaneler-ve-gercekler/

Çalışkanoğlu, Şahin. "Imam-Hatip Lisesi Öğrencilerinin Sorun ve Beklentileri (Çorum Örneği)". Yüksek Lisans Tezi, Hitit Üniversitesi, 2018.

Çelik, Ömer Faruk. "Katsayı Uygulamasının Kaldırılması Sonrasında İmam Hatip Lisesi Öğrencilerinin Davranış, Tutum ve Özellikleri (Gaziantep Örneği)”. Yüksek Lisans Tezi, Uludağ Üniversitesi, 2016.

Din Öğretimi Genel Müdürlüğü. "Uluslararası Anadolu İmam Hatip Liseleri". Erişim 13 Ekim 2020. http://dogm.meb.gov.tr/pdf/UAlHL_Tanitim.pdf

DOGM. "Anadolu İmam Hatip Liselerinde Program Çeşitliliği (Proje Okullar)". Erişim 13 Ekim 2020. https://dogm.meb.gov.tr/meb_iys_dosyalar/2019_04/29212747_ProgramCesitliligi.pdf

Ece, Ömer Yunus. "Anadolu İmam Hatip Lisesi eğitim programına yönelik öğrenci ve öğretmen görüşleri (Kartepe ilçesi örneği)". Yüksek Lisans Tezi, Sakarya Üniversitesi, 2018.

Eğitimciler Birliği Sendikası (Eğitim-Bir-Sen). Rakamlarla 28 Şubat Raporu. Ankara: Eğitimciler Birliği Sendikası, 2014.

Eğitimsen. "2017'de Eğitimde Neler Oldu". Erişim 02.04.2020. http://egitimsen.org.tr/2017de-egitimde-neler-oldu/

Eğitimsen. 2016-2017 Eğitim-Öğretim Yılı Sonunda Eğitimin Durumu. Ankara: Eğitim ve Bilim Emekçileri Sendikası, 2017. Erişim http://egitimsen.org.tr/wp-content/uploads/2017/09/Eğitimin-Durumu-Raporu-13-Eylül-2017.pdf

ERG. Eğitim Reformu Girişimi. Eğitim İleme Raporu 2014-15. Eğitim Reformu Girişimi, 2015. Erişim http://www.egitimreformugirisimi.org/wp-content/uploads/2017/03/ERG_ElR_2014-15.pdf

ERG. Eğitim Reformu Girişimi. Eğitim İleme Raporu 2017-2018. İstanbul: Eğitim Reformu Girişimi, 2018.

ERG. Eğitim Reformu Girişimi. Eğitimin Içcriği Eğitim İleme Raporu 2020. İstanbul: Eğitim Reformu Girişimi, 2020.

ILKE. Eğitim İzleme Raporu 2019. İstanbul: İLKE İlim Kültür Eğitim Vakfı, 2020.

Kanburoğlu, Betül Ü. "Popüler Kültür-Din Eğitimi İlişkisi: İmam Hatip Liseleri örneği”. Yüksek Lisans Tezi, Marmara Üniversitesi, 2011.

Karasubaşı, Ömer Alper, Akın Uğur ve Nail Yıldırım. "Öğrenci ve Mezunlarının Perspektifinden İmam Hatip Liselerinin Değerlendirilmesi". Değerler Eğitimi Dergisi 18/39 (2019): 65-105. 
Karateke, Tuncay. “Imam-Hatip Lisesi Öğrencilerinin Sorun ve Beklentileri (Batman Ili Örneği)". Yüksek Lisans Tezi, Frrat Üniversitesi, 2010.

Kaya, Nurcan. Türkiye Eğitim Sisteminde Renk, Etnik Köken, Dil, Din ve Inanç Temelli Ayrımcllık. İstanbul: Tarih Vakfı, Uluslararası Azınlık Hakları Grubu MRG, 2015.

Kaya, Zeynep. "Illahiyat Dışında Lisans Eğitimi Planlayan İmam-Hatip Lisesi Öğrencilerinin Meslek Dersleri İle İlgili Değerlendirmeleri Üzerine Nitel Bir Araştırma". İslam Medeniyeti Araştırmaları Dergisi 3/1 (2018): 61-96.

Kervankaya, Figen. "İmam Hatip Liselerinde Arapça Öğretimi Üzerine Bir Değerlendirme”. Eskişehir Osmangazi Üniversitesi Ilahiyat Fakültesi Dergisi 1 (2014): 125-134.

Korkmaz, Mehmet. "İmam Hatip Lisesi Öğrencilerinin Bu Okulu Tercih Süreçleri: Nasıl? ve Neden?". 100. Yılında Imam Hatip Liseleri. ed. Recep Kaymakcan vd. İstanbul: Değerler Eğitimi Merkezi, 2015.

Milli Eğitim Bakanlığı. “Milli Eğitim İstatistikleri Örgün Eğitim 2019/2020”. Erişim 5 Kasım 2020. http:// sgb.meb.gov.tr/www/milli-egitim-istatistikleri-yayinlanmistir-orgun-egitim-20192020/ice$\mathrm{rik} / 397$

Özdemir, Şuayip ve Tuncay Karateke. "Öğrencilerin İmam Hatip Liselerini Tercih Etme Nedenleri (Elazığ Örneği)". OMUIFD: Ondokuz Mayis University Review of the Faculty of Divinity 45 (2018): ss.

Özensel, Ertan ve Mehmet Ali Aydemir. Türkiye Imam Hatip Lisesi Öğrenci Profili Araştırması (Temel Sorunlar, Beklentiler ve Değer Yapıları). Türkiye İmam-Hatipliler Vakfı, 2014. Erişim http:// timav.org.tr/wp-content/uploads/2016/03/T\%C3\%BCrkiye-\%C4\%BOmam-Hatip-Lisesi-\%C3\%96\%C4\%9Frenci-Profili-Ara\%C5\%9Ft\%C4\%B1rmas\%C4\%B1.pdf

Özensel, Ertan, Mahmut Hakkı Aydın ve Mehmet Ali Aydemir. Türkiye'de Imam Hatip Lisesi ve Imam Hatipliler Algısı. Türkiye İmam-Hatipliler Vakfı, 2012. Erişim http://timav.org.tr/wp-content/uploads/2016/03/Türkiyede-Imam-Hatip-Liseleri-ve-Imam-Hatipliler-Algısı-Kamuoyu-Araştırması.pdf

Patton, M. Quinn. Nitel Araştırma ve Değerlendirme Yöntemleri. Ankara: Pegem Akademi, 2018.

TEDMEM. 2014 Eğitim Değerlendirme Raporu. Ankara: Türk Eğitim Derneği, 2014. Erişim https:// tedmem.org/download/2014-egitim-degerlendirme-raporu?wpdmdl=997\&refresh=5e8f7cff38f121586461951

TEDMEM. 2015 Eğitim Değerlendirme Raporu. Ankara: Türk Eğitim Derneği, 2015. Erişim https:// tedmem.org/download/2015-egitim-degerlendirme-raporu? wpdmdl=1341\&refresh $=5$ e8f809a2041c1586462874

TEDMEM. 2017 Eğitim Değerlendirme Raporu, İstanbul: Türk Eğitim Derneği, 2018. Erişim https://tedmem.org/download/2017-egitim-degerlendirme-raporu?wpdmdl=2564\&refres$\mathrm{h}=5 \mathrm{e} 8 \mathrm{f} 7 \mathrm{~d} 284 \mathrm{~d} 9741586461992$

TEDMEM. 2018 Eğitim Değerlendirme Raporu. (TEDMEM Değerlendirme Dizisi 5). Ankara: Türk Eğitim Derneği, 2019.

TEDMEM. 2019 Eğitim Değerlendirme Raporu. (TEDMEM Değerlendirme Dizisi 6). Ankara: Türk Eğitim Derneği, 2020.

TiMAV. Türkiye İmam-Hatipliler Vakfı. Türkiye'de Din Öğretimi Forumu Sonuç Raporu. Konya: 2012. Erişim http://timav.org.tr/wp-content/uploads/2016/03/T\%C3\%BCrkiyede-Din-\%C3\%96\%C4\%9Fretimi-Forumu-Sonu\%C3\%A7-Raporu.pdf

TiMAV. Türkiye İmam-Hatipliler Vakfı. Imam Hatip Liseleri, Sorunlar ve Çözüm Önerileri Çalıştayı Sonuç Raporu. Konya: 2015. Erişim http://timav.org.tr/wp-content/uploads/2016/09/\%C4\%BOmam-Hatiplerde-Kalite-\%C3\%87al\%C4\%B1\%C5\%9Ftay\%C4\%B1.pdf 


\section{MÎZÂNÜ'L-HAK \\ ISLAMI ILIMLER DERGISI}

TiMAV. Türkiye İmam-Hatipliler Vakfı. Imam Hatiplerde Mesleki Müfredat ve Program Çeşitliliği Çalıştayı Sonuç Raporu. 2017. Erişim http://timav.org.tr/wp-content/uploads/2017/03/Müfredat-ÇalıştayI-RAPOR-SONNNN.pdf

Türk Eğitim-Sen. Türkiye'de Din Eğitimi Çalıştayı. Ankara: Türk Eğitim-Sen, 2015. Erişim https://www. turkegitimsen.org.tr/lib_yayin/395.pdf

Uzpeder, Ebru vd. Gündelik Hayatta Laiklik Pratikleri. İstanbul:Yurttaşlık Derneği, 2010. Erişim https:// hyd.org.tr/attachments/article/260/gundelik-hayatta-laiklik-pratikleri.pdf

Ünsür, Ahmet. Kuruluşundan Günümüze Imam-Hatip Liseleri. İstanbul: Ensar Neşriyat, 2005.

Vural, Ayşe. "İmam-Hatip Lisesi Son Sınıf Öğrencilerinin Mesleki Yeterlilik Algısı". Yüksek Lisans Tezi, Ondokuz Mayıs Üniversitesi, 2016.

Yıldııım, Ali ve Hasan Şimşek. Sosyal Bilimlerde Nitel Araştırma Yöntemleri. Ankara: Seçkin Yayınları, 2018.

Zeytinoğlu, Yasemin. "Okuluma Dokunma Koordinasyonu Pratiğinde, İmam Hatip'e Dönüştürülen Devlet Okullarının Durumu". Öğretmenler, Öğrenciler, Veliler ve STK'lar Açısından Eğitim Sisteminde Din Öğretiminin Rolü içinde, 51-62. İstanbul: Yurttaşlık Derneği, 2016. Erişim https://www.hyd.org.tr/attachments/article/201/egitim-sisteminde-din-ogretiminin-rolu.pdf 